\title{
BIMBINGAN TEKNIS PENGOLAHAN NILAI MELALUI PEMANFAATAN APLIKASI BERBASIS MS.EXCEL UNTUK MENINGKATKAN KEMAMPUAN GURU DALAM MENGOLAH DATA HASIL EVALUASI PEMBELAJARAN
}

\section{Iseu Marlaiseu}

\author{
SDN Cibabat Mandiri 2, Cimahi, Jawa Barat, Indonesia
}

iseumarlaise@gmail.com

\begin{abstract}
ABSTRAK
Penilaian merupakan salah satu cara untuk mengetahui tingkat ketercapaian tujuan pembelajaran bagi setiap komponen proses belajar mengajar. Dari Hasil Pengamatan yang dilakukan oleh peneliti tentang Kemampuan Guru Dalam Mengolah Data Hasil Evaluasi Pembelajaran, dapat diketahui bahwa kemampuan guru dalam hal ini belum optimal. Guru seringkali masih menemukan kesulitan dalam pengolahan hasil evaluasi, terutama yang menggunakan aplikasi komputer. Guna mengatasi masalah tersebut perlu diadakannya suatu bimbingan untuk mengatasinya. Jenis penelitian ini adalah penelitian tindakan sekolah yang meliputi 2 siklus tindakan. Dalam satu siklus terdapat masing-masing satu tindakan. Setiap siklus terdapat berbagai instrumen yang berfungsi sebagai refleksi pada siklus berikutnya. Subjek penelitian ini adalah guru Di SD Negeri Cibabat Mandiri 2 Kecamatan Cimahi Utara Kota Cimahi Semester 1 Tahun Pelajaran 2018-2019. Pengumpulan data dilakukan dengan menggunakan lembar observasi, wawancara, tes hasil belajar, studi dokumentasi dan dokumen analisis data. Penelitian dimulai sejak bulan Juli 2018 sampai Desember 2018. Hasil penelitian ini menunjukkan bahwa bimbingan teknis mampu meningkatkan kemampuan guru dalam mengolah hasil evaluasi menggunakan MS.Excel, yang dilaksanakan pada guru-guru SD Negeri Cibabat Mandiri 2 Kecamatan Cimahi Utara Kota Cimahi Semester 1 Tahun Pelajaran 2018-2019.
\end{abstract}

Kata Kunci: Kompetensi Guru, Mengolah Hasil Evaluasi, MS.Excel

\begin{abstract}
Assessment is one way to determine the level of achievement of learning objectives for each component of the teaching and learning process. From the observations made by researchers about the ability of teachers to process data on learning evaluation results, it can be seen that the ability of teachers in this case is not optimal. Teachers often find difficulties in processing evaluation results, especially those using computer applications. In order to overcome this problem, a guidance is needed to overcome it. This type of research is school action research which includes 2 cycles of action. In one cycle there is one action each. Each cycle has a variety of instruments that serve as a reflection on the next cycle. The subjects of this study were teachers at Cibabat Mandiri 2 Public Elementary School, Cimahi Utara District, Cimahi City, 1st Semester 2018-2019 Academic Year. Data collection is done by using observation sheets, interviews, learning outcomes tests, study documentation and data analysis documents. The study began in July 2018 until December 2018. The results of this study indicate that technical guidance is able to improve the ability of teachers to process evaluation results using MS. Excel, which was conducted at Cibabat Mandiri 2 Elementary School teachers in North Cimahi District, Cimahi City, Semester 1 Academic Year 2018-2019.
\end{abstract}

Keywords: Teacher Competence, Processing Evaluation Results, MS. Excel 


\section{PENDAHULUAN}

Pendidikan diyakini merupakan faktor paling dominan dalam pengembangan kualitas SDM. Hampir semua negara selalu memprioritaskan programnya pada sektor pendidikan. Berbagai upaya telah dilakukan untuk meningkatkan mutu pendidikan pada semua jenjang. Salah satu upaya untuk meningkatkan mutu pendidikan dilakukan melalui program pengembangan manajemen sekolah. Kualitas pendidikan sangat ditentukan oleh beberapa faktor, antara lain kemampuan satuan pendidikan dalam mengelola proses pembelajaran dan penilaian.

Penilaian hasil belajar merupakan aktivitas yang sangat penting dalam proses pendidikan. Semua proses di lembaga pendidikan formal pada akhirnya akan bermuara pada hasil belajar yang diwujudkan secara kuantitatif berupa nilai. Hasil belajar siswa tidak selalu mudah untuk dinilai. Sebagaimana diketahui, tujuan pembelajaran meliputi ranah kognitif, afektif dan psikomotor. Ranah pengetahuan (kognitif) dan sikap (afektif) relatif sulit untuk diamati, meski pun dapat diukur. Oleh karena itu, dalam proses penilaian hasil belajar langkah yang pertama harus dimulai dari perumusan tujuan pembelajaran yang memungkinkan untuk diamati dan diukur (observable and measurable). Berangkat dari tujuan pembelajaran yang dirumuskan, maka disusunlah instrument untuk mengamati dan mengukur hasil pembelajaran. Dengan menggunakan instrumen, diperoleh data yang mencerminkan ketercapaian tujuan pembelajaran pada seorang peserta didik. Data ini selanjutnya harus diolah dan dimaknai sehingga menjadi informasi yang bermakna. Selain itu berdasarkan data tersebut penilai dapat membuat keputusan mengenai posisi atau status seorang peserta didik, misalnya naik atau tidak naik kelas, lulus atau tidak dan sebagainya. Seluruh proses penilaian hasil belajar tentu harus dilakukan dengan cermat, mulai dari penyusunan instrumen, pelaksanaan tes, pengolahan, sampai pada penetapan hasil akhir. Pada setiap tahapan diperlukan keterampilan khusus yang perlu dipelajari.

Penilaian merupakan salah satu cara untuk mengetahui tingkat ketercapaian tujuan pembelajaran bagi setiap komponen proses belajar mengajar terutama peserta didik. Guru dapat melakukan penilaian dengan cara mengumpulkan catatan yang diperoleh melalui pertemuan, observasi, portofolio, proyek, produk, ujian, serta data hasil interview dan survey. Setiap sekolah memiliki sistem penilaian belajar siswa tiap semester yang bertujuan untuk mengetahui 
perkembangan kualitas siswa, proses, dan kemajuan hasil belajar peserta didik sesuai dengan kemampuan yang dimilikinya, juga sekaligus sebagai umpan balik bagi guru untuk dapat menyempurnakan pembelajaran.

Kemajuan teknologi modern khususnya yang berkaitan dengan kemajuan komputer merupakan salah satu faktor yang mempengaruhi pembaharuan, tidak hanya dalam sektor bisnis, telekomunikasi, tetapi juga dalam dunia pendidikan. Hal tersebut karena komputer memiliki fitur-fitur dan aplikasiaplikasi canggih yang dapat meringankan dan mempermudah pekerjaan seseorang sehingga dapat dikatakan hampir semua orang memiliki ketergantungan dengan keberadaan komputer. Dunia pendidikan pun saat ini diharapkan sudah memanfaatkan kecanggihan teknologi komputer karena dapat membantu mencapai sasaran dan tujuan pendidikan sehingga proses belajar mengajar akan lebih berkesan dan bermakna.

Pemanfaatan komputer yang dimaksud adalah pemanfaatan komputer oleh guru untuk menunjang tugas, meningkatkan kualitas dan kinerja guru dalam kegiatan belajar mengajar. Sangat disayangkan apabila sistem informasi penilaian hasil belajar di sekolah masih menggunakan sistem informasi penilaian secara manual yang dianggap kurang efektif dan efisien karena dapat menyebabkan terjadinya beberapa kesalahan, baik kesalahan dalam penulisan ataupun perhitungan. Masih banyak sekolah-sekolah yang menggunakan cara manual untuk menyampaikan sistem informasi penilaian hasil belajar siswa, yaitu menggunakan buku rapor sebagai medianya, sehingga pengolahan data nilai siswa membutuhkan waktu yang lama dan informasi yang dihasilkan kurang lengkap.

Aplikasi manajemen sistem informasi penilaian akademik siswa merupakan salah satu alternatif dalam mengatasi permasalahan tersebut. Pemanfaatan kecanggihan teknologi informasi yang ada saat ini akan berdampak pada keefektifan dan keefisienan proses penilaian akademik siswa. Salah satu teknologi informasi yang dapat diterapkan adalah teknologi internet sehingga sistem informasi penilaian akademik siswa dapat dilakukan secara online dan berbasis komputer. Sistem informasi penilaian akademik berbasis komputer dan online memang terkesan lebih modern, efektif, dan efisien karena bisa diakses dimanapun dan kapanpun.Mewujudkan sebuah sistem informasi diperlukan faktor-faktor penunjang antara lain minat guru dalam 
mengembangkan sistem informasi penilaian hasil belajar, pemanfaatan dan pemahaman komputer oleh guru, dan persepsi guru tentang iklim sekolah.

Dalam evaluasi pembelajaran, yang menjadi obyek penilaian adalah proses dan hasil belajar. Substansinya adalah sejauh mana proses pembelajaran dilakukan oleh guru dan siswa dan sejauh mana tujuantujuan pembelajaran belajar dicapai siswa. Dengan demikian dalam evaluasi pembelajaran, data yang harus dikumpulkan adalah data tentang aktivitas pembelajaran dan data tentang hasil belajar. Data proses pembelajaran lebih banyak berupa data kualitatif, sedangkan data hasil belajar lebih banyak data yang bersifat kuantitatif, berupa angka. Dalam pengolahan data kualitatif, biasanya lebih banyak dilakukan secara subyektif oleh guru, dengan bersandar pada ilmu pengetahuan dan ilmu pendidikan yang dimilikinya. Sedangkan data kuantitatif berupa angka-angka, dalam pengolahan dan analisisnya menggunakan alat Bantu sistem operasi matematik dan/atau statistik.

Berhubungan dengan pengolahan dan analisis data berupa angka (numerik), dewasa ini kita bisa menggunakan salah satu program aplikasi komputer, yaitu program pengolah data. Salah satu program yang bisa digunakan untuk mengolah data angka tentang proses dan hasil belajar adalah program Microsoft Excel. Oleh karena itu peneliti tertarik untuk menelaah dan memberikan kemampuan teknis bagi para guru, dalam memanfaatkan tknologi khususnya program Microsoft Excel dalam pengolahan hasil belajar. Hal ini dituangkan dalam sebuah penelitian yang berjudul "Bimbingan Teknis Pengolahan Nilai Melalui Pemanfaatan Aplikasi Berbasis Ms.Excel Untuk Meningkatkan Kemampuan Guru Dalam Mengolah Data Hasil Evaluasi Pembelajaran (PTS pada guru-guru di SD Negeri Cibabat Mandiri 2 Kecamatan Cimahi Utara Kota Cimahi Semester 1 Tahun Pelajaran 2018-2019)

Adapun tujuan dari penelitian ini adalah (1) Untuk mengetahui Apakah kegiatan bimbingan teknis pengolahan nilai melalui pemanfaatan aplikasi berbasis MS.excel, dapat meningkatkan kemampuan guru dalam mengolah data hasil evaluasi pembelajaran.; (2) Untuk mendeskripsikan proses peningkatan kemampuan guru dalam mengolah data hasil evaluasi pembelajaran, setelah diadakannya kegiatan bimbingan teknis pengolahan nilai melalui pemanfaatan aplikasi berbasis MS.excel.; (3) Untuk mengetahui seberapa besar peningkatan kemampuan 
guru dalam mengolah data hasil evaluasi pembelajaran, setelah diadakannya kegiatan bimbingan teknis pengolahan

\section{KAJIAN PUSTAKA}

1) Kompetensi Guru

Menurut kamus besar bahasa Indonesia, kompetensi adalah kewenangan (kekuasaan) untuk menentukan (memutuskan) sesuatu (Djamarah, 1994 : 33). Guru merupakan kunci keberhasilan sebuah lembaga pendidikan. Baik atau buruknya perilaku atau cara mengajar guru akan sangat mempengaruhi citra pendidikan. Oleh sebab itu, sumber daya guru ini harus dikembangkan baik melalui pendidikan dan pelatihan dan kegiatan lain agar kemampuan profesionalnya lebih meningkat, sehingga setiap guru memiliki kompetensi profesional. Dalam hal inilah guru perlu mengetahui dan memahami kompetensi sebagai guru, dalam rangka turut serta mencerdaskan kehidupan bangsa, peranan guru sangat penting sekali untuk membentuk sumber daya manusia yang berkualitas dan berakhlak mulia. Kita sadari, bahwa peran guru sampai saat ini masih eksis, sebab sampai kapanpun posisi atau peran guru tersebut tidak akan bisa digantikan sekalipun dengan mesin sehebat apapun, mengapa? Karena, guru sebagai seorang pendidik juga membina sikap nilai melalui pemanfaatan aplikasi berbasis MS.excel.

mental yang menyangkut aspek- aspek manusiawi dengan karakteristik yang beragam dalam arti berbeda antara satu siswa dengan lainnya. Banyak pengorbanan yang telah diberikan oleh seorang guru semata-mata ingin melihat anak didiknya bisa berhasil dan sukses kelak. Tetapi perjuangan guru tersebut tidak berhenti sampai disitu, guru juga merasa masih perlu meningkatkan kompetensinya agar benar-benar menjadi guru yang lebih baik dan lebih profesional terutama dalam proses belajar mengajar sehari-hari.

Pada dasarnya terdapat seperangkat tugas yang harus dilaksanakan oleh guru berhubungan dengan profesinya sebagai pengajar, tugas guru ini sangat berkaitan dengan kompetensi profesionalnya. Hakikat profesi guru merupakan suatu profesi, yang berarti suatu jabatan yang memerlukan keahlian khusus sebagai guru dan tidak dapat dilakukan oleh sembarang orang di luar bidang pendidikan. Walaupun pada kenyataannya masih terdapat hal-hal tersebut di luar bidang kependidikan. 
Ciri seseorang yang memiliki kompetensi apabila dapat melakukan sesuatu, hal ini sesuai dengan pendapat Munandar bahwa, kompetensi merupakan daya untuk melakukan suatu tindakan sebagai hasil dari pembawaan dan latihan. Pendapat ini, menginformasikan dua faktor yang mempengaruhi terbentuknya kompetensi, yakni; faktor bawaan, seperti bakat, dan faktor latihan, seperti hasil belajar.

\section{2) Evaluasi Pembelajaran}

Secara harfiah kata evaluasi berasal dari bahasa Inggris education; dalam bahasa Arab: At-Taqdir; dalam bahasa Indonesia berarti penilaian. Dengan demikian secara harfiyah dapat evaluasi pendidikan diartikan sebagai penilaian dalam bidang pendidikan atau penilaian mengenai hal yang berkaitan dengan kegiatan pendidikan.

Adapun dari segi istilah, sebagaimana dikemukakan oleh Edwind Wandt dan Gerald W. Brown (1977) evaluasi adalah suatu tindakan atau suatu proses untuk menentukan nilai dari sesuatu. Apabila definisi Edwind Wandt dan Gerald W. Brown (1977) digunakan untuk memberi definisi tentang evaluasi pendidikan, maka evaluasi pendidikan itu dapat diberi pengertian sebagai suatu tindakan atau kegiatan (yang dilaksanakan dengan maksud untuk) atau suatu proses (yang berlangsung dalam rangka) menentukan nilai dari segala sesuatu dalam dunia pendidikan (yaitu segala sesuatu yang berhubungan dengan, atau yang terjadi di lapangan pendidikan). Atau singkatnya evaluasi pendidikan adalah kegiatan atau proses penentuan nilai pendidikan sehingga dapat diketahui mutu atau hasil- hasilnya.

Menurut Guba dan Lincoln evaluasi merupakan suatu proses memberikan pertimbangan mengenai nilai dan arti sesuatu yang dipertimbangkan. Sesuatu yang dipertimbangkan itu bisa berupa orang, benda, kegiatan atau keadaan tertentu. dari konsep diatas ada dua hal yang menjadi karakteristik evaluasi. Pertama, evaluasi merupakan suatu proses. Artinya, dalam suatu pelaksanaan evaluasi mestinya terdiri dari beberapa macam tindakan yang harus dilakukan. Kedua, evaluasi berhubungan dengan pemberian nilai atau arti. Artinya, evaluasi dapat menunjukan kualitas yang dinilai.

Dari penjelasan di atas, maka pengukuran adalah proses pengumpulan data yang diperlukan dalam rangka memberikan judgement yakni berupa keputusan terhadap sesuatu. 
Pengukuran yang bersifat kuantitatif itu dapat dibedakan menjadi tiga macam, yaitu:

1. Pengukuran yang dlakukan bukan untuk menguji sesuatu. Misalnya pengukuran yang dilakukan penjahit pakaian.

2. Pengukuran yang dilakukan untuk menguji sesuatu. Misalnya pengukuran untuk menguji daya tahan perbaja terhadap tekanan berat.

3. Pengukuran untuk menilai, yang dilakukan dengan jalan menguji sesuatu.

Misalnya pengukuran kemajuan belajar peserta didik dalam rangka mengisi nilai rapor yang dilakukan dengan menguji mereka dalam bentuk tes hasil belajar. Pengukuran jenis ketiga inilah yang digunakan dalam dunia pendidikan. Penilaian berarti menilai sesuatu. Sedangkan menilai adalah mengambil keputusan terhadap sesuatu dengan mendasarkan diri atau berpegang pada ukuran baik dan buruk, sehat atau sakit, pandai atau bodoh dan sebagainya. Jadi penilaian itu sifatnya adalah kualitatif.

Sedangkan evaluasi adalah mencakup dua kegiatan tadi, yaitu pengukuran dan penilaian. Evaluasi adalah kegiatan atau proses untuk menilai sesuatu. Untuk dapat menentukan nilai dari sesuatu yang sedang dinilai itu dilakukanlah pengukuran, dan wujud dari pengukuran itu adalah pengujian, dan pengujian inilah yang dalam dunia kependidikan dikenal dengan istilah tes. Lebih lanjut dikatakan bahwa istilah penilaian mempunyai arti yang lebih luas di bandingkan dengan istilah pengukuran. Sebab pengukuran itu sebenarnya hanyalah merupakan suatu langkah atau tindakan yang kiranya perlu diambil dalam rangka pelaksanaan evaluasi. Dikatakan "perlu diambil" karena tidak semua penilaian itu harus senantiasa di dahului oleh tindakan pengukuran secara lebih nyata.

Namun demikian tidak dapat disangkal adanya kenyataan bahwa evaluasi dalam bidang pendidikan, sebagian besar bersumber dari hasil-hasil pengukuran. Evaluasi mengenai proses pembelajaran disekolah tidak mungkin dapat terlaksana dengan baik apabila evaluasi itu tidak didasarkan atas data yang bersifat kuantitatif. Inilah sebabnya mengapa dalam praktek masalah pengukuran mempunyai kedudukan yang sangat penting dalam proses evaluasi. Baik buruknya evaluasi akan bergantung pada hasil- hasil pengukuran yang mendahuluinya. Hasil pengukuran yang kurang cermat akan memberikan hasil evaluasi yang kurang 
cermat pula ; sebaliknya teknik pengukuran yang tepat diharapkan dapat memberikan landasan yang kokoh untuk mengadakan evaluasi yang tepat.

\section{3) Bimtek Pengolahan Nilai Melalui} Pemanfaatan Aplikasi Berbasis MS. excel

Pendidikan diyakini merupakan faktor paling dominan dalam pengembangan kualitas SDM. Hampir semua negara selalu memprioritaskan programnya pada sektor pendidikan. Berbagai upaya telah dilakukan untuk meningkatkan mutu pendidikan pada semua jenjang. Kualitas pendidikan sangat ditentukan oleh beberapa faktor, antara lain kemampuan satuan pendidikan dalam mengelola proses pembelajaran dan penilaian.

Penilaian merupakan salah satu cara untuk mengetahui tingkat ketercapaian tujuan pembelajaran bagi setiap komponen proses belajar mengajar terutama peserta didik. Guru dapat melakukan penilaian dengan cara mengumpulkan catatan yang diperoleh melalui pertemuan, observasi, portofolio, proyek, produk, ujian, serta data hasil interview dan survey. Setiap sekolah memiliki sistem penilaian belajar siswa tiap semester yang bertujuan untuk mengetahui perkembangan kualitas siswa, proses, dan kemajuan hasil belajar peserta didik sesuai dengan kemampuan yang dimilikinya, juga sekaligus sebagai umpan balik bagi guru untuk dapat menyempurnakan pembelajaran.

Kemajuan teknologi modern khususnya yang berkaitan dengan kemajuan komputer merupakan salah satu faktor yang mempengaruhi pembaharuan, tidak hanya dalam sektor bisnis, telekomunikasi, tetapi juga dalam dunia pendidikan. Hal tersebut karena komputer memiliki fitur-fitur dan aplikasiaplikasi canggih yang dapat meringankan dan mempermudah pekerjaan seseorang sehingga dapat dikatakan hampir semua orang memiliki ketergantungan dengan keberadaan komputer. Dunia pendidikan pun saat ini diharapkan sudah memanfaatkan kecanggihan teknologi komputer karena dapat membantu mencapai sasaran dan tujuan pendidikan sehingga proses belajar mengajar akan lebih berkesan dan bermakna. Pemanfaatan komputer yang dimaksud adalah pemanfaatan komputer oleh guru untuk menunjang tugas, meningkatkan kualitas dan kinerja guru dalam kegiatan belajar mengajar.

Sangat disayangkan apabila sistem informasi penilaian hasil belajar di sekolah masih menggunakan sistem informasi 
penilaian secara manual yang dianggap kurang efektif dan efisien karena dapat menyebabkan terjadinya beberapa kesalahan, baik kesalahan dalam penulisan ataupun perhitungan. Masih banyak sekolah-sekolah yang menggunakan cara manual untuk menyampaikan sistem informasi penilaian hasil belajar siswa, yaitu menggunakan buku rapor sebagai medianya, sehingga pengolahan data nilai siswa membutuhkan waktu yang lama dan informasi yang dihasilkan kurang lengkap.

Aplikasi manajemen sistem informasi penilaian akademik siswa merupakan salah satu alternatif dalam mengatasi permasalahan tersebut. Pemanfaatan kecanggihan teknologi informasi yang ada saat ini akan berdampak pada keefektifan dan keefisienan proses penilaian akademik siswa. Salah satu aplikasi yang dapat digunakan untuk mendukung penilaian adalah Microsoft Excel. Untuk mewujudkan sebuah sistem informasi diperlukan faktor- faktor penunjang antara lain minat dan kemampuan guru dalam mengolah penilaian hasil belajar, kemampuan dan pemahaman komputer guru harus memadai. Oleh karena itu

\section{METODE PENELITIAN}

Metode penelitian yang digunakan dalam penelitian ini adalah metode deskriftif dibutuhkan sebuh bimbingan teknis agar guru dapat terampil memanfaatkan Excel, untuk mengolah hasil evaluasi pembelajaran.

Excel adalah program spreadsheet dalam sistem Microsoft Office. Kita dapat menggunakan Excel untuk membuat dan memformat workbook untuk menganalisis data dan membuat data itu sendiri. Secara khusus, kita dapat menggunakan Excel untuk melacak data, membangun model untuk menganalisis data, menulis rumus untuk melakukan perhitungan pada data itu, memproses data dalam berbagai cara, dan menyajikan data dalam berbagai grafik. Lembar keja dalam Microsoft Excel dalam satu sheet terdiri dari 256 kolom (columns) dan 65536baris (rows). Kolom ditampilkan dalam tanda huruf A, B, C dan berakhir pada kolom IV. Sedangkan baris dilambangkan dalam bentuk angka 1, 2, 3 dan berakhir pada 65536. Perpotongan antara baris dan kolom disebut sel (cell), misal, pada perpotongan kolom B dengan baris ke 5 disebut sel B5. Dansel yang bergaris tebal menandakan bahwa sel tersebut dalam keadaan aktif.

analitik, yaitu studi yang digunakan untuk mengumpulkan data, mendeskripsikan, mengolah, menganalisa, menyimpulkan 
dan menafsirkan data sehingga diperoleh gambaran yang sistematis (Winarno Surachmad, 1982:135). Metode penelitian deskriptif analisis digunakan untuk mengetahui permasalahan dengan cara mengurai secara rinci dan jelas, serta melakukan suatu analisis data dari permasalahan untuk memperoleh suatu kesimpulan dengan tujuan untuk menggambarkan dan menganalisis secara

\section{HASIL PENELITIAN}

1) Hasil Pra Siklus

Dari data awal dapat dilihat, bahwa guru yang memiliki kemampuan dalam mengolah hasil evaluasi menggunakan MS.Excel masih sangat rendah, hanya beberapa guru yang dikategorikan cukup sistematis terhadap suatu fakta yang sifatnya faktual. Penelitian ini dilaksanakan di SD Negeri Cibabat Mandiri 2 Kecamatan Cimahi Utara Kota Cimahi. Penelitian dilaksanakan pada guruguru, dimaksudkan agar guru-guru dapat memanfaatkan teknologi yang dapat membantu pengolahan nilai. Dalam hal ini menggunakan MS. Excel.

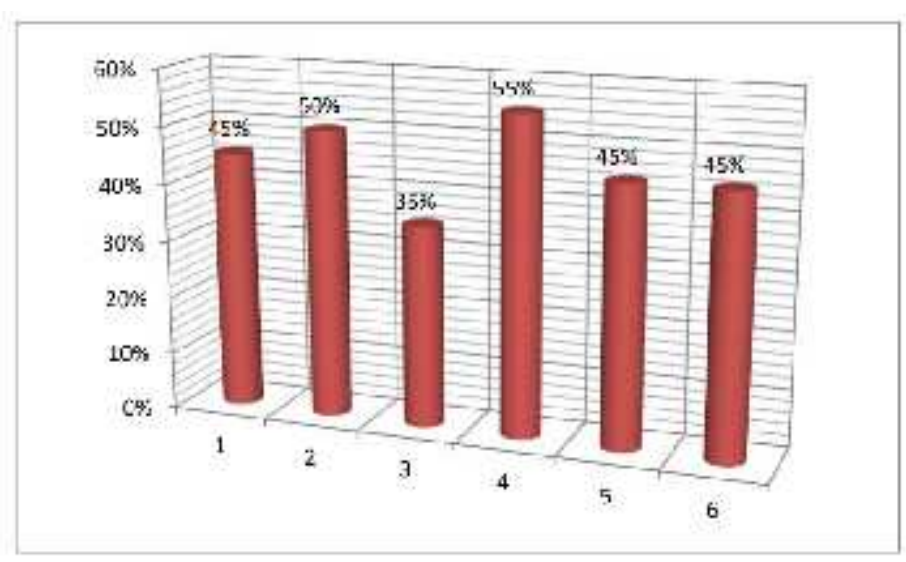

Grafik 1. Kemampuan Guru Pra Siklus 
2) Hasil Siklus 1

Berdasarkan data pada siklus 1 , menunjukkan bahwa dari 6 orang guru, sebanyak 1 orang guru dalam kategori sangat baik, sebanyak 4 orang guru termasuk kategori Baik, dan sebanyak 1

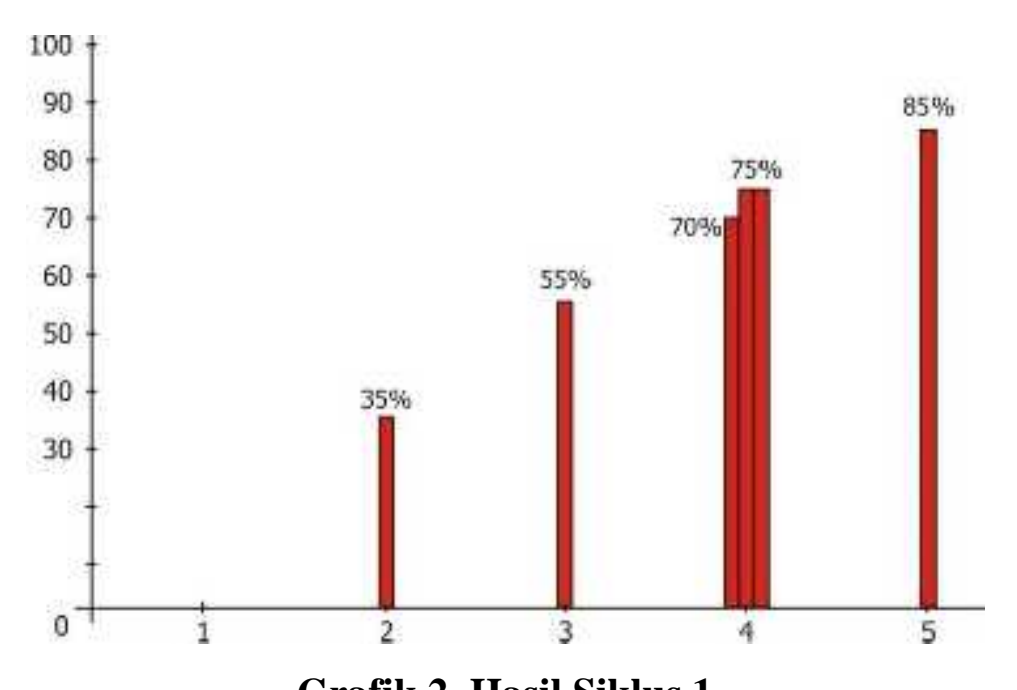

Grafik 2. Hasil Siklus 1

\section{3) Hasil Siklus 2}

Setelah kegiatan siklus 2, diperoleh data bahwa Pada siklus II ini, menunjukkan peningkatan kemampuan dari 6 orang guru, sebanyak 3 orang guru dalam kategori Sangat Baik, sebanyak 1 orang guru termasuk kategori Baik, dan untuk kategori cukup ada 2 orang, dan tidak terdapat kategori yang kurang. Dari data tersbut masih terlihat keaktifan guru yang kurang sehingga untuk siklus berikutnya dianggap sudah baik. orang guru dalam kategori kurang. Dari data tersbut masih terlihat kemampuan guru yang kurang sehingga untuk siklus berikutnya harus diperbaiki agar lebih baik. Adapun hasil siklus 1 dapat dilihat pada grafik 2 berikut : 


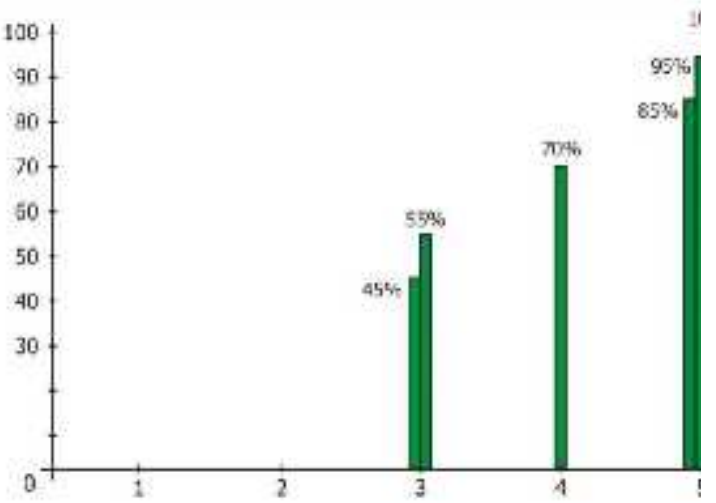

Grafik 3. Hasil Siklus

\section{4) Peningkatan}

Bila diuraikan dalam bentuk grafik maka peningkatan kemampuan guru dalam pengolahan nilai pada Pra Siklus, siklus I dan Siklus II dapat dilihat pada grafik berikut ini

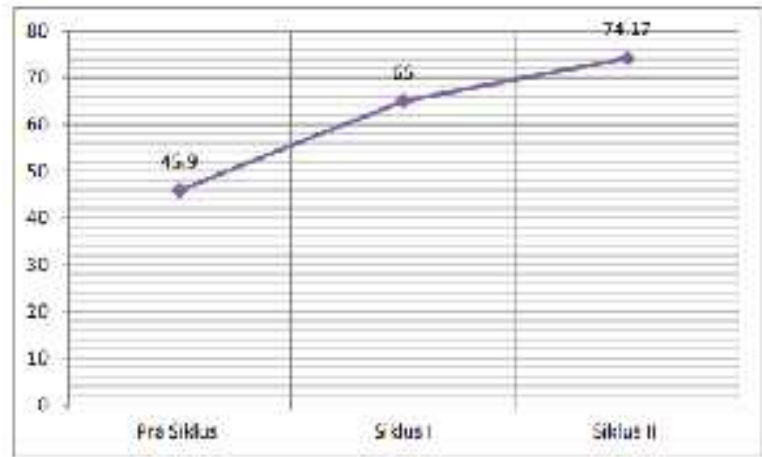

\section{KESIMPULAN}

Berdasarkan hasil pembahasan dapat ditarik kesimpulan bahwa bimbingan teknis mampu meningkatkan kemampuan guru dalam mengolah hasil evaluasi menggunakan MS.Excel, yang dilaksanakan pada guru-guru SD Negeri Cibabat Mandiri 2 Kecamatan Cimahi Utara Kota Cimahi Semester 1 Tahun Pelajaran 2018-2019. Ini didukung dengan data, bahwa pada awalnya kemampuan guru dalam mengolah hasil evaluasi menggunakan MS.Excel baru sebesar 45,9\% sedangkan pada siklus I meningkat menjadi senbesar $65 \%$, dan pada siklus II pun meningkat lagi menjadi 74,17\%. Hal ini menunjukkan bahwa semua guru telah mampu mengolah hasil evaluasi menggunakan MS.Excel, selain itu memiliki pandangan yang positif dan menginginkan proses pembelajaran menjadi efektif dan efisien yang ditunjang dengan pemanfaatan teknologi.

\section{DAFTAR PUSTAKA}

Djam'an, Satori, dkk, 2007. Profesi

Keguruan. Jakarta: Universitas Terbuka. Jogiyanto. 2000.“Sistem Informasi Berbasis

Komputer”. Yogyakarta: BPFE-

Yogyakarta.

Mulyasa, E, 2007. Kurikulum Tingkat Satuan

Pendidikan. Bandung: PT Remaja

Rosdakarya, cetakan keempat.

Peraturan Menteri Pendidikan Nasional

Nomor 66 Tahun 2013 Tentang

StandarPenilaian Pendidikan.

Reynold, C.R., et al. (2010). Measuremet and assesment in education. New York:

Pearson.

Rusman Dkk, 2012, Pembelajaran Berbasis teknologi Informasi dan komunikasi, Jakarta, PT. Rajawali

Saudagar, Fachruddin, dk, 2009.

Pengembangan Profesionalitas Guru. Jakarta: Gaung Persada Press. 